\title{
Module Curriculum Construction of Diversified College ESP English Basing on Demand Analysis
}

\author{
Yilan $\mathrm{Du}^{1, \mathrm{a}}$ \\ ${ }^{1}$ Nanchang Institute of Science and Technology, 330108 \\ aduyilanjx@126.com
}

Keywords: demand analysis; diversification; college ESP English courses

\begin{abstract}
Combining with ESP(English for Specific Purposes) theory and demand analysis, there is a result on the social and study need for the diversified college ESP English class. It turns out there is a strict demand for students' English ability. This paper aims at analyzing the construction of college ESP English program and improving students practical abilities.
\end{abstract}

\section{General Description of College ESP English Courses}

Influenced by the globalization of economy and higher education, more requirements have been raised to our college English teaching lessons and students study. To meet this development, adjustments of college English lessons have been made centering the international lessons and ESP courses.ESP lessons mostly refer to the relevance between English theme and propositions and other specific subjects, events and occupations basing on the learning and targets needs[1]. ESP courses can realize the need for different students at different levels, emphasize on the practical use of English into other aspects of social life. After some concordance work done in the English side, students will be guided using quite different study methods and techniques to learn English. According to different purposes and language environments, ESP courses can be divided into professional English and academical English[2]. Professional English refers to those working in a specific field like electricity, business and so on; academical English, otherwise, refers to a deeper and more specified research study of English, which can still be divided into specific academic English and academic English. Under the trend of ESP English program, academic English attracts more attention than before. More and more countries have already set up ESP English courses proving the increasing need for college English in the global environment.

\section{Construction Demand For Diversified College ESP English Courses}

Demand analysis bases on the domestic environment stressing on practical events. Considering different countries, cultural levels and target groups, demand analysis makes it possible to meet different needs with different courses. Before meet the different needs of students, the very first thing is to meet the demand conditions of students[3]. ESP courses aims at designing particular timetables for students, so it is necessary to understand their concrete study tasks and working conditions. According to their requirements, actual gaps of students between their current levels and ideal levels should be analyzed on the demand analysis. Demand analysis forms a prerequisite in ESP courses construction also acts as a theory foundation for courses implement and evaluation. It also can help shape the ESP courses teaching goals and outlines effectively improve the teaching quality. Students demands include the following four aspects in Chart 1.

Chart 1 Demands for English learning improvement of students

\begin{tabular}{|c|c|c|c|}
\hline English lectures & $\begin{array}{c}\text { Professional } \\
\text { reading }\end{array}$ & $\begin{array}{c}\text { Professional thesis } \\
\text { writing }\end{array}$ & $\begin{array}{c}\text { Professional } \\
\text { discussion }\end{array}$ \\
\hline $27.6 \%$ & $26.5 \%$ & $25.6 \%$ & $23.5 \%$ \\
\hline
\end{tabular}


Courses need to consider students and society demands. Students demands includes their study needs and their weakness in learning skills and knowledge. Social demands refers to the English requirements from enterprises and societies. In addition, the requirements for qualified teachers showed up together. Students current situations includes their own learning tendency, attitude, style, methods and their majors and professional abilities.

\section{Module Courses Construction of Diversified College ESP}

\section{Demand analysis}

Based on demand analysis to construct a course, it can help curriculum developers to choose suitable mode for English Teaching, such as conditions, students knowledge learning, learning skills, learning motivation and learning strategies.Based on the construction of Diverse ESP English "Module" Curriculum System, it can be adjusted at the same time and shift the focus of the different students' English learning ability.Because of there exist certain differences of students of different professions and levels.In order to ensure that ESP English can meet the learning needs of most students, we need ESP English modular. For the orientation of academic English, we meet different levels of students academic communication ability needs. To meet the students' learning needs and improve their English and oral proficiency in the field of students 'professional English, we develop the syllabus to develop students 'academic communication ability. According to students' needs, it can regularly carry out English lectures, group discussions to guide students to write professional papers and other professional literature.

\section{Construction of Module Curriculum}

By analyzing students professional direction, learn knowledge content, subjective needs of individual awards, English course is divided into several modules, including professional English module, academic skill module and language basic module,etc. and the core course is based on the module contents[6]. Academic skills modules include academic reading, vocabulary, writing and other courses. They can help students improve the reading ability to quickly extract information, and speculate on the terminology of terminology according to the context of the article to speculate on the terminology as well as improve the reading ability and vocabulary memory. Language-based module for students who need for individual learning or basic supplementary requirements, including the division English and the skills of large English module. Division English is on the basis of comprehensive English and according to students' background and teaching materials to learn English knowledge. Skills English mainly includes spoken English, listening, reading and translation, writing and other English single skills courses to meet the students learning different skills. Learning Skills module is interdisciplinary, which suit for a wide range of courses, including academic English listening and speaking as well as reading and writing the two core, and all courses are equipped with basic English language skills training.

Because of there are some differences of learning ability and learning attitude when different English proficiency students in the ESP "module" course learning, it can provide some guidance to help students Language organization in teaching, such as: topics selecting, information retrieval, literature review and paper writing to ensure the accuracy of terminology. At the end of the course, students will be given the opportunity to select a topic to complete a small research paper and present oral presentations in the classroom.

\section{Summary}

As an unique design of English courses, ESP English courses are made on students language foundation, tasks and demands. Combing with the study demand and social demand, ESP English module courses are constructed to satisfy different levels and kinds of students. Attending this kind of courses, students can reflect their needs and demands at any time to adjust their own teaching goals, in this way can perform a more efficient and dynamic language learning timetable and module. 


\section{Reference}

[1] Xueqing Fu. Research and Thoughts on College English Follow-up Elective Courses on Demand Analysis[J]. Computer-assisted Foreign Language Education, 2014,02: 74-78.

[2] Xiujuan Wang, Yunzhang Shi. Integration of ESP and College English_Exploration on ESP Courses Construction in Local Universities[J]. Science \& Technology Vision, 2014, 11: 36+55.

[3] Xiaodan Hou, Yongliang Ma, Tingting Gao. Demand Analysis on ESP English Courses for Non-English Major Students__ A Practical Research on College English Module Transform from EGP to ESP[J]. Journal of Dalian University, 2014, 03:141-144.

[4] Mingjie Bao. College English ESP Teaching Research Basing on Demand Analysis[J]. Hubei Social Sciences, 2013, 12:191-193.

[5] Nanyun Li. Speaking Teaching Strategy Analysis on College Non-English Major Students under ESP Demand Analysis[J]. Journal of Xuchang University, 2013, 01:141-144.

[6] Bingli Liu. Primary College English Teaching Research on ESP Demand Analysis[J]. China Educational Technology \& Equipment, 2015, 11:5-6. 